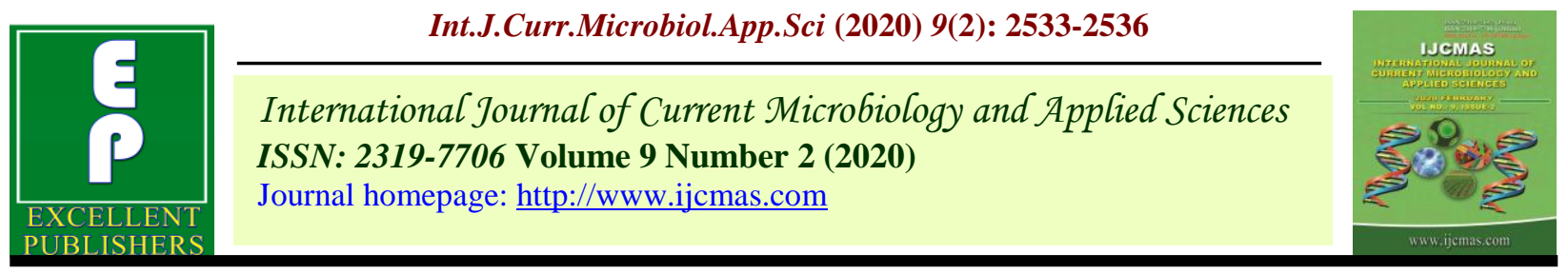

Original Research Article

https://doi.org/10.20546/ijcmas.2020.902.288

\title{
Assessment of Genetic Variability, Heritability and Genetic Advance of Newly Evolved Genotype of Chrysanthemum (Dendranthema grandiflora Tzvelev) for Cut Flower Production
}

\author{
Reshma Negi $^{1^{*}}$, S. R. Dhiman ${ }^{1}$ and M. R. Dhiman ${ }^{2}$ \\ ${ }^{1}$ The Department of Floriculture and Landscape Architecture, Dr. Yashwant Singh Parmar \\ University of Horticulture and Forestry, Nauni, Solan, Himachal Pradesh, PIN-173230, India \\ ${ }^{2}$ ICAR-IARI Regional Research Station, Katrain Kullu (H.P), India \\ *Corresponding author
}

\section{A B S T R A C T}

\begin{tabular}{|l|}
\hline Ke y w o r d s \\
Experiment, \\
Genetic Variability, \\
Heritability, \\
Genetic advance, \\
Department
\end{tabular}

Ke ywords

Experiment,

Genetic Variability,

Heritability,

Genetic advance,

Department

Article Info

Accepted:

Available Online:

10February 2020

\begin{abstract}
An experiment was conducted to study genetic variability, heritability and genetic advance among nineteen genotypes of newly evolved genotypes of chrysanthemum (Dendranthema grandiflora Tzvelev) for cut flower production at the experimental farm of ICAR-IARI Regional Research Station, Katrain, Kullu (H.P) for two successive years during 20172018. A wide range of variation in performance of the genotypes were recorded for various parameters and results shows that magnitude of the phenotypic coefficient of variation (PCV) was higher than Genetic Coefficient of variance (GCV) exhibiting that genotype and environment interaction. High (> 98.09\%) PCV and GCV was observed for plant height, plant spread, number of stems per plant, flower diameter, days taken to flowering, duration of flowering, stem length, weight of cut stem, number of flowers per stem. Heritability estimates range from moderate to high i.e. (46.02) days taken to bud formation to plant height (98.09). Estimates of high heritability along with high genetic advance as percent GAM recorded for all vegetative and flowering parameters exhibiting the additive gene effect which could be further used for crop breeding programme.
\end{abstract}

\section{Introduction}

Chrysanthemum (Dendranthema grandiflora Tzvelev) belongs to family Asteraceae (Andreson, 1987) and native to northern hemisphere chiefly Europe and Asia. It is national flower of Japan and commonly called as "Queen of the East," Guldaudi in India and mum in America. The number of species in the genus chrysanthemum varies from 100 to 200. It ranks second after rose in spray and seventh in standard type of flower production.
In India during 2016-2017 the area under chrysanthemum was 20090 hectare and production of loose flower was 185240 MT and cut flower was 14930 MT of cut flower (Anonymous, 2018). Total area under chrysanthemum in Himachal Pradesh for cut flower and loose flower production is $67.01 \mathrm{ha}$ and 155.10 ha with annual production of 5360 lakh number of cut flower and 3102 thousand MT of loose flower respectively during the year 2018-2019 (Directorate of H.P). 
Chrysanthemum has wide range of flower colour, shape, size and growth habit. It is used for cut flower and loose flower as well as making garlands, venis, gajras and religious offering. Chrysanthemum is a short day plant and cannot normally form flower buds when the day length exceeds 14.5 hours and developed them when it exceeds 13.5 hours (Machin and Scopes, 1978). Due to nature of flowering under short-day conditions, availability of chrysanthemum flower is restricted to short span of not more than three months. But as a result of intensive research by scientists and practical experience of many growers, its flowers can be produced throughout the year to precise schedules at any time by environmental manipulation, fertilization and using growth regulating chemical. Every year many varieties are being added to long list by the government and private agencies. So, there is wide range of variation, but very little attention has been given for its improvement, there is an urgent need to identify varieties suitable for growing in different agro climatic conditions for specific purposes. For success of any breeding programme information on the nature and magnitude of variability present in existing material and association among the various characters is prerequisite for any breeding programme for high yield and quality. Keeping in mind, the investigation was carried out with objective to study the nature and extent of variability present in newly evolved genotype of chrysanthemum and to identify elite genotypes to be used in hybridization programme to bring desired improvement for crop yield /cut flower production.

\section{Materials and Methods}

An experiment was conducted to study of genetic variability, heritability and genetic advance among nineteen genotypes of newly evolved genotypes of chrysanthemum
(Dendranthema grandiflora Tzvelev) namely UHFSChr111, UHFSChr113, UHFSChr114, UHFSChr115, UHFSChr117, UHFSChr118, UHFSChr120, UHFSChr121,UHFSChr122, UHFSChr123, UHFSChr124,UHFSChr125, UHFSChr126, UHFSChr128, UHFSChr129, UHFSChr130, UHFSChr131, UHFSChr132, including 'Ajay' as check for cut flower production at the experimental farm at ICARIARI Regional Research Station, Katrain for two successive years during 2017-2018. The plants were planted in three replications in Randomized Block Design in open field conditions using FYM $5 \mathrm{~kg} / \mathrm{m}^{2}$ and supplemented with NPK @ $30 \mathrm{~g} / \mathrm{m}^{2}$, respectively. Various intercultural operations like; hoeing, weeding and staking and other management practices were carried out as and when required and duration of flowering. Observations were recorded for different plant parameters viz., days taken for flowering, plant height $(\mathrm{cm})$ recorded at the time of flowering etc. Phenotypic and genotypic coefficient of variations and heritability (Burton and Devene, 1953) and Genetic advance (Johnson et al., 1995) were estimated.

\section{Results and Discussion}

Perusal of pooled data in Table 1 a wide range of variability for all characters except number of cut stems per plant, flower diameter, number of cut stems per plant was reported and also found that genotypic co-efficient of variation was lesser than the phenotypic coefficient of variation such variation was also reported by Ponuswami et al., (1985). Among eleven characters range of GCV for various characters varied from 0.89 (days taken to bud formation to 43.05 (number of flowers per plant). High phenotypic and genotypic coefficient were found for the traits like number of flowers per plant $(\mathrm{GCV}=43.55$; $\mathrm{PCV}=44.52)$ and number of flowers per stem $(\mathrm{PCV}=67.20 ; \mathrm{GCV}=34.00)$ the result was close conformity to Hamalata et al., (1992). 
The large amount of variability between GCV and PCV indicates that characters are influenced by environment factors such as number of flowers per plant, flower diameter, number of cut stems per plant, weight of cut stem, plant height. All parameters have wide range of variation suggesting the presence of large amount of variability and affected by environmental factors, it is difficult to improve through selection. All the parameters show low range of GCV than PCV was observed for days taken to bud formation, days taken to flowering and stem length these traits expressed the true genetic potential in varied environments.

Table.1 Pooled parameters of variability for cut flower under Katrain conditions

\begin{tabular}{|c|c|c|c|c|c|c|c|}
\hline \multirow[t]{2}{*}{ Characters } & \multirow[t]{2}{*}{ Mean \pm SE $(\mathrm{m})$} & \multirow[t]{2}{*}{ Range } & \multicolumn{2}{|c|}{$\begin{array}{l}\text { Coefficients of } \\
\text { variability }(\%)\end{array}$} & \multirow[t]{2}{*}{ Heritability (\% } & \multirow[t]{2}{*}{$\begin{array}{l}\text { Genetic } \\
\text { advance }\end{array}$} & \multirow[t]{2}{*}{$\begin{array}{c}\text { Genetic gain } \\
(\%)\end{array}$} \\
\hline & & & PCV & GCV & & & \\
\hline Plant height (cm) & $87.61 \pm 1.86$ & $65.50-119.00$ & 16.34 & 16.19 & 98.09 & 28.93 & 33.02 \\
\hline Plant spread (m) & $34.25 \pm 0.31$ & $28.25-40.55$ & 6.72 & 4.83 & 51.67 & 2.45 & 7.15 \\
\hline $\begin{array}{c}\text { No of cut stem per } \\
\text { plant }\end{array}$ & $5.38 \pm 0.13$ & $3.50-7.00$ & 18.86 & 16.05 & 72.40 & 1.51 & 28.14 \\
\hline Flower diameter $(\mathrm{cm}$ & $4.90 \pm 0.20$ & $3.30-10.25$ & 31.52 & 31.02 & 96.83 & 3.08 & 62.88 \\
\hline $\begin{array}{l}\text { Days taken to bud } \\
\text { formation }\end{array}$ & $150.00 \pm 0.26$ & $145.50-155.5($ & 1.31 & 0.89 & 46.02 & 1.86 & 1.24 \\
\hline $\begin{array}{l}\text { Days taken to } \\
\text { flowering }\end{array}$ & $178.82 \pm 0.73$ & $162.50-185.5 c$ & 3.13 & 3.02 & 93.08 & 10.72 & 6.00 \\
\hline Duration of flowerin: & $29.13 \pm 0.59$ & $23.50-37.00$ & 15.42 & 14.89 & 93.29 & 8.63 & 29.63 \\
\hline Stem length $(\mathrm{cm})$ & $71.89 \pm 1.16$ & $53.00-99.50$ & 12.43 & 12.05 & 94.10 & 17.31 & 24.09 \\
\hline weight of cut stem (g & $31.87 \pm 0.74$ & $23.00-44.50$ & 17.83 & 16.87 & 89.56 & 10.48 & 32.90 \\
\hline No of flowers per plar & $43.01 \pm 2.49$ & $7.90-94.95$ & 44.52 & 43.55 & 95.66 & 37.74 & 87.74 \\
\hline No of flowers /stem & $18.48 \pm 1.63$ & $2.87-14091.1 ?$ & 67.20 & 34.00 & 25.60 & 6.55 & 35.43 \\
\hline
\end{tabular}

For evaluation the amount of heritable variation, estimate of GCV alone is not enough. Heritability variability can be evaluated with great degree of accuracy, where heritability is studied in conjunction with genetic advance. All parameter under study were high heritability in broadsence from low to high from 46.02 (days taken to bud formation) to 98.09 (plant height) present in Table1. High heritability indicates that less influence by the environment. The result was close conformity with the findings of Sirohi and Behera (2000), Baskaran et al., (2004), Misra (2006) and Poornima et al., (2007), Hebbal et al.,.(2018). High genetic advance was observed with number of flowers per plant (37.74), plant height (28.93) and stem length (17.31). High heritability was mainly due to additive gene action, it would be associated with high genetic gain and if it is due to non additive gene action, genetic gain would be low (Panse, 1957). Number of flowers per plant, plant height, days taken to flowering, stem length, Genotype which exhibited both high variability and high genetic advance for certain character may be evaluated in multilocation trial and isolated as donors for this character or used as parents in hybrid development programme. 


\section{References}

Anderson RL.1987.Reclassification of genus chrysanthemum Hort Science 22: 313.

Anonymous. 2017. Flora Holland https://www.royalfloraholland.com/en /speciale-paginas/ in... /bloemenagenda-2017.

Anonymous.2017.RoyalFloraHollandAnnualr eport.http://annualreport.royalfloraholl and.com/?_ga=2.4001779.296685808. $1547377011841489915.1547377011 \# /$ feiten-en-cijfers?_k=0fe151.

Anonymous. 2018. Ministry of Agriculture, Government of India (https:www.indiastat.com/).

Behra T.K, PS Sirohi and Pal A.2002.assessement of chrysanthemum germplasm for commercial cultivation under Delhi condition. Journal of Ornamental Horticulture New Series 5:11-14.

Baskaran, V., Janakiram, T. and Jayanthi, R. 2004. Correlation and path coefficient analysis studies in chrysanthemum. Journal of Ornamental Horticulture. 7 (3-4): 37-44.

Burton GW and De Vane EH. 1953. Estimating heritability in tall fescue (Festuca arundinacea) from replicated clonal material. Agronomy Journal 45: 478-481.

Johanson HW, Robinson HF and Comstock RE. 1955. Estimates of genetic and environmental variability in soyabean. Agronomy Journal 47: 314-318.

Hemalatha B., Patil A.A. and Nalawadi U.G. 1992. Variability studies in chrysanthemum. Prog. Hort., 24: 5559.

Hebbal M, Shiragur M, Naika B.N.,. Seetharamu G.K, Nishani S. and B.C. Patil, 2018. Assessment of Genetic Variability, Heritability and Genetic Advance in Chrysanthemum (Dendranthema grandiflora Tzvelve). Int.J.Curr.Microbiol.App.Sci. 7(08): 4544-4553

Machin BJ, Scopes NEA 1978. Chrysanthemum year round growing. Bladford Press, Poole-Dorset, p 233.

Mishra, H.N., Das, J.N. and Palai, S.K. 2006. Character association and path coefficient analysis in spray type chrysanthemum. Orissa J. of Hort., 34 (2): 32-33.

Ponnuswamy V, Chezhiyan N, Khader JMA and Thamburaj S. 1985. Genetic variability in chrysanthemum. South Indian Horticulture 33(3): 211-213.

\section{How to cite this article:}

Reshma Negi, S. R. Dhiman and Dhiman' M. R. 2020. Assessment of Genetic Variability, Heritability and Genetic Advance of Newly Evolved Genotype of Chrysanthemum (Dendranthema grandiflora Tzvelev) for Cut Flower Production. Int.J.Curr.Microbiol.App.Sci. 9(02): 2533-2536. doi: https://doi.org/10.20546/ijcmas.2020.902.288 